\title{
Subconjunctival Loa loa worm: first case report in Brazil
}

\author{
Verme subconjuntival da espécie Loa loa: primeiro caso no Brasil
}

Renato Magalhães Passos ${ }^{1}$, Carolina Pelegrini Barbosa ${ }^{1}$, Juliana de Souza Almeida², Guilherme Maerschner Ogawa ${ }^{3}$, Luis Marcelo Aranha Camargo ${ }^{4}$

\begin{abstract}
We report the first case of ocular infestation by Loa loa in Brazil. Loiasis is caused by infestation with Loa loa, a filarial parasite originally found in the rainforests of western and central Africa. It is transmitted by the bite of the fly Chrysops and has been recently described in other places other than Africa, in African immigrants or travellers. Our case is a 33 year-old woman from Cameroon who was living in São Paulo, Brazil, for 5 years. She was asymptomatic until one morning she started feeling "something moving" in the left eye. Under topical anesthesia, on the slit lamp, a moving worm was removed from the subconjunctival space, which later was confirmed to be a male Loa loa adult specimen. Blood tests revealed microfilaraemia of $129 \mathrm{mf} / \mathrm{mL}$. The patient was treated with $400 \mathrm{mg}$ oral albendazole for 3 weeks and $60 \mathrm{mg}$ prednisone. This report illustrates an unusual ocular disease, which is extremely rare outside of Africa but easily diagnosed and treated. Ophthalmologists should be aware of it, in face of an increasingly globalized world.
\end{abstract}

Keywords: Loa; Loiasis; Conjunctival diseases/parasitology; Eye infections, parasitic/ parasitology; Filariosis; Brazil; Case reports

\section{RESUMO}

Este é o primeiro relato na literatura nacional e internacional de infestação ocular por Loa loa no Brasil. A loíase é uma filariose causada pelo parasita Loa loa, encontrado nas florestas tropicais da África equatorial. A transmissão se dá pela picada do mosquito Chrysops e casos têm sido descritos em países não africanos, em imigrantes eviajantes. O presente caso trata-se de uma paciente de 33 anos natural de Camarões e residente em São Paulo, Brasil, há 5 anos. Até então assintomática, uma manhã sentiu algo "se mexendo" em seu olho esquerdo. Sob anestesia tópica, na lâmpada de fenda, um verme altamente móvel foi removido do espaço subconjuntival e enviado para identificação, que confirmou tratar-se de um espécime macho adulto de Loa loa. Testes sanguíneos revelaram microfilaremia de $129 \mathrm{mf} / \mathrm{mL}$. A paciente foi tratada com albendazol $400 \mathrm{mg}$ e prednisona $60 \mathrm{mg}$ esquema regressivo por 3 semanas. Este relato ilustra uma doença excepcionalmente rara no Brasil, e praticamente desconhecida dos oftalmologistas em nosso país.

Descritores: Loa; Loíase; Doenças da túnica conjuntiva/parasitologia; Infecções oculares parasitárias/parasitologia; Filariose; Brasil; Relatos de casos

\section{INTRODUCTION}

Loa loa infestation fits in the category of helminthic diseases called filariases. It is popularly known as "African eye worm", due to a peculiar ocular manifestation of the disease ${ }^{(1)}$. The adult worms live freely in the subcutaneous space of humans and occasionally may migrate into the subconjunctival space ${ }^{(2)}$ where they invariably produce exuberant symptoms such as ocular pain, pruritus, tearing and foreign body sensation ${ }^{(3)}$. The adult worm has been described also in the anterior chamber of the eye and in the subcutaneous of the eyelids ${ }^{(4)}$. Other common manifestations are the so-called Calabar swellings: localized angioedemas found predominantly in the limbs, near the joints ${ }^{(5)}$.

The nematode is transmitted by the bite of an infected Chrysops fly. Both the agent and vector are originally found only in equatorial Africa ${ }^{(1)}$. The disease affects millions of people in that region but is rarely found in other continents, generally in African immigrants or travelers (the disease may remain asymptomatic for several years) ${ }^{(1)}$ In fact, there are only case reports in sporadic countries: USA, Germany, Spain, Italy, Norway, Korea, Australia, to name a few ${ }^{(2,4-11)}$ (Table 1). This is the first case described in Brazil.

\section{CASE REPORT}

A 33 year-old woman presented to our emergency service complaining of "something moving" in the left eye. She was original from Cameroon and was living in São Paulo, Brazil, for five years. She denied previous ocular or systemic symptoms. General physical examination was unremarkable with no evidence of subcutaneous swellings. On slit lamp examination, a moving opalescent worm was seen in the subconjunctival space of the left eye. Under topical anesthesia, a small incision was made in the superior conjunctiva and the worm was extracted intact with a forceps (Figure 1). It was immediately placed in saline (later transferred to ethanol 70\%) and sent for a specialized Parasitology Department. The worm was identified as an adult male Loa loa measuring $33 \mathrm{~mm}$ long and $0.4 \mathrm{~mm}$ wide.

Blood was collected from two different sites at 12 o'clock (Loa loa microfilariae have diurnal periodicity, with the highest load in the blood stream found at noon). Two methods were used to search for and identify the microfilariae: membrane filtration and thick blood smear. Microfilariae were found in both methods. In membrane filtration, $1 \mathrm{~mL}$ of blood was diluted in $10 \mathrm{~mL}$ of saline solution and filtered in polycarbonate filters with $25 \mathrm{~mm}$ diameter and micropo-
Submitted for publication: February, 11, 2011

Accepted for publication: September 14, 2011

Study carried out at the Departamento de Oftalmologia da Universidade Federal de São Paulo UNIFESP - and at the Instituto de Ciências Biológicas da Universidade de São Paulo - USP - Porto Velho (RO).

${ }^{1}$ Physician, Department of Ophthalmology, Universidade Federal de São Paulo - UNIFESP - São Paulo (SP), Brazil.

2 Biomedical, Department of Medicine, Faculdade São Lucas, Porto Velho (RO), Brazil.

${ }^{3}$ Biologist, Biomedical Science Institute 5, Universidade de São Paulo - USP - Rondônia, Brazil.

${ }^{4}$ Physician, Biomedical Science Institute 5, Universidade de São Paulo - USP - Rondônia, Brazil.
Funding: No specific financial support was available for this study.

Disclosure of potential conflicts of interest: R.M.Passos, None; C.P.Barbosa, None; J.S.Almeida, None; G.M.Ogawa, None; L.M.A.Camargo, None.

Correspondence address: Renato M. Passos. Rua Botucatu, 821 - São Paulo (SP) - 04024-062 Brazil -E-mail: renatompassos@yahoo.com.br 
Table 1. A few case reports of ocular Loiasis outside Africa

\begin{tabular}{|c|c|c|c|c|c|}
\hline Patient & $\begin{array}{c}\text { Ocular } \\
\text { manifestations }\end{array}$ & $\begin{array}{c}\text { Extra-ocular } \\
\text { manifestations }\end{array}$ & $\begin{array}{l}\text { Last exposure in } \\
\text { endemic region }\end{array}$ & Treatment & Reference \\
\hline $\begin{array}{l}\text { Brazil, african } \\
\text { 33yo immigrant }\end{array}$ & $\begin{array}{c}\text { Subconjunctival } \\
\text { worm }\end{array}$ & None & 5 years & $\begin{array}{l}\text { Worm removal + } \\
\text { albendazole + } \\
\text { prednisone }\end{array}$ & Passos et al, 2011 \\
\hline $\begin{array}{l}\text { England, african } \\
21 \text { yo medical student }\end{array}$ & $\begin{array}{c}\text { Subconjunctival } \\
\text { worm }\end{array}$ & $\begin{array}{l}\text { Calabar swelling } \\
\text { in the elbow }\end{array}$ & 6 years & $\begin{array}{c}\text { Worm removal + } \\
\text { diethylcarbamazine + } \\
\text { prednisolone }\end{array}$ & Bowler et al, $2011^{(8)}$ \\
\hline $\begin{array}{l}\text { Italy, swiss } \\
\text { 33yo woman }\end{array}$ & $\begin{array}{c}\text { Subconjunctival } \\
\text { worm }\end{array}$ & None & 7 years & Worm removal & Aiello et al, $2010^{(7)}$ \\
\hline $\begin{array}{l}\text { Norway, norwegian } \\
\text { 38yo woman }\end{array}$ & $\begin{array}{l}\text { Subconjunctival } \\
\text { worm }\end{array}$ & $\begin{array}{l}\text { Sporadic episodes of } \\
\text { worm movement in } \\
\text { subcutaneous tissues }\end{array}$ & $\begin{array}{c}\text { Worked regularly in } \\
\text { african countries }\end{array}$ & $\begin{array}{l}\text { Worm removal + } \\
\text { diethylcarbamazine }\end{array}$ & Varhaug, $2009^{(6)}$ \\
\hline $\begin{array}{l}\text { Australia, nigerian } \\
42 \text { yo immigrant }\end{array}$ & $\begin{array}{l}\text { Subconjunctival } \\
\text { worm }\end{array}$ & None & 2 years & $\begin{array}{l}\text { Worm removal + } \\
\text { albendazole + } \\
\text { prednisone }\end{array}$ & Jain et al, 2008 \\
\hline $\begin{array}{l}\text { South Korea, african } \\
29 y o \text { immigrant }\end{array}$ & $\begin{array}{c}\text { Subconjunctival } \\
\text { worm }\end{array}$ & $\begin{array}{l}\text { Calabar swelling } \\
\text { on the forearm }\end{array}$ & 5 years & $\begin{array}{l}\text { Worm removal + } \\
\text { ivermectin }\end{array}$ & Cho et al, $2008^{(5)}$ \\
\hline $\begin{array}{l}\text { Spain, african } \\
24 y o \text { immigrant }\end{array}$ & $\begin{array}{c}\text { Subconjunctival } \\
\text { worm }\end{array}$ & None & $\begin{array}{l}\text { Visited Cameroon } \\
\text { once a year }\end{array}$ & Worm removal & $\begin{array}{l}\text { López-Rodríguez } \\
\text { et al, 2007(9) }\end{array}$ \\
\hline $\begin{array}{l}\text { USA, african } \\
29 y o \text { immigrant }\end{array}$ & $\begin{array}{l}\text { Subconjunctival } \\
\text { worm }\end{array}$ & None & Not described & Worm removal & Nam et al, 2008 ${ }^{(10)}$ \\
\hline $\begin{array}{l}\text { Germany, african } \\
23 y o \text { student }\end{array}$ & $\begin{array}{l}\text { Eyelid subcutaneous } \\
\text { worm }\end{array}$ & $\begin{array}{l}\text { Calabar swelling } \\
\text { on the forearms }\end{array}$ & 5 years & $\begin{array}{l}\text { Worm removal + } \\
\text { diethylcarbamazine }\end{array}$ & Sbeity et al, 2006 ${ }^{(11)}$ \\
\hline $\begin{array}{l}\text { India, indian } \\
48 y o \text { man }\end{array}$ & $\begin{array}{c}\text { Anterior chamber } \\
\text { worm }\end{array}$ & None & Never went to Africa & $\begin{array}{l}\text { Worm removal + } \\
\text { diethylcarbamazine + } \\
\text { prednisolone }\end{array}$ & Barua et al, 2005(4) \\
\hline
\end{tabular}
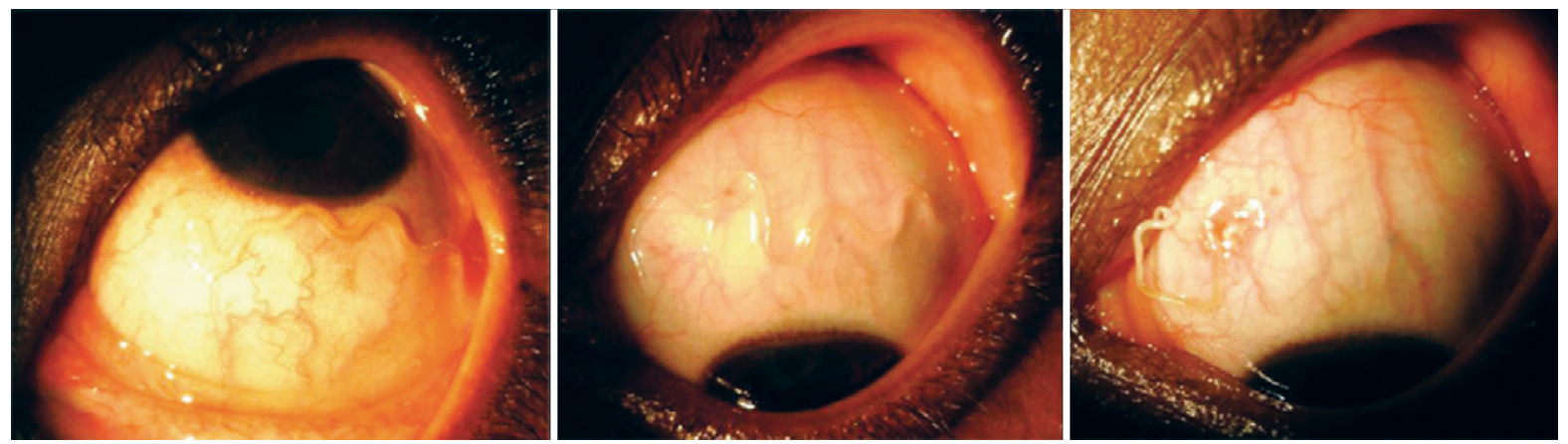

Figure 1. Highly mobile worm in the subconjunctival space and its removal through small incision under topical anesthesia.

res of 3-5 $\mu \mathrm{m}$. Both membrane and thick smears were stained with Giemsa. The analysis was made in a light microscope with 10x, 40x and 100x amplification. The average microfilariae concentration was $129 \mathrm{mf} / \mathrm{mL}$. The species identification of Loa loa was confirmed by the presence of a huge sheath and the presence of nuclei reaching the tip of the tail (Figure 2).

After the diagnostic confirmation of loiasis, the patient was called back for treatment. She received $400 \mathrm{mg}$ oral albendazole for 3 weeks and $60 \mathrm{mg}$ prednisone tapered over 3 weeks.

\section{DISCUSSION}

Loiasis is the disease characterized by the infestation by Loa loa, a nematode belonging to the order Spirurida, superfamily Filaroidea ${ }^{(2)}$. This group includes all worms commonly known as "filariae", causative agents of a group of diseases called filariases ${ }^{(1)}$. Among those, three species are known to affect the eye: Loa loa, Onchocerca volvulus and Mansonella perstans. However, the ocular manifestations of these three agents vary greatly and the differential diagnosis usually can be made based on clinical and epidemiological thinking (Table 2).

Onchocerciasis or "river blindness" (caused by Onchocerca volvulus) has been considered one of the main causes of blindness in equatorial Africa and also in indigenous tribes in the Amazon Forest. It typically affects the cornea (progressive sclerosing keratitis), anterior chamber (chronic uveitis) or posterior segment (chorioretinitis, optic neuropathy), but the adult worm can never be seen in the subconjunctival space (they reside mainly in subcutaneous nodules) ${ }^{(12)}$.

Mansonella perstans have the same geographic distribution of Onchocerca. In fact, coinfection by filarial agents is commonly found in Africa. The ocular manifestations of mansonelliasis resemble those of loiasis, but differ greatly from those of onchocerciasis. In the first two diseases, the adult worm may migrate from the subcutaneous 

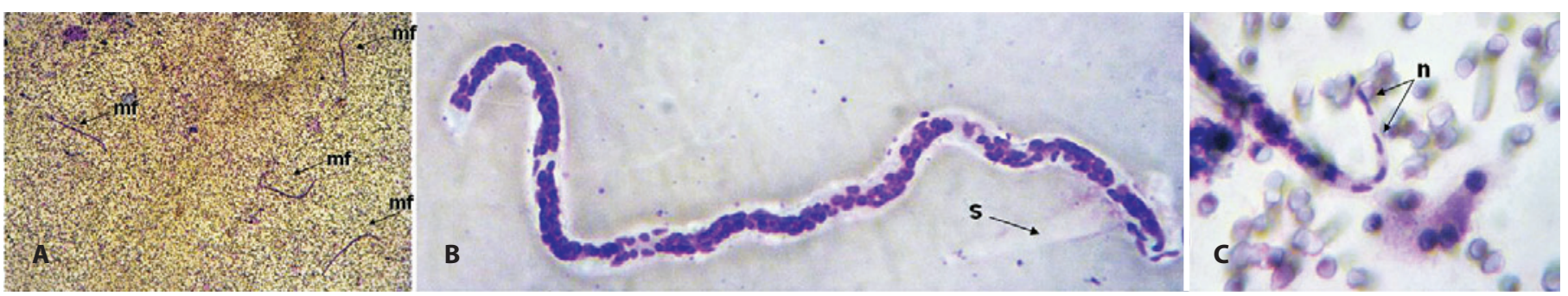

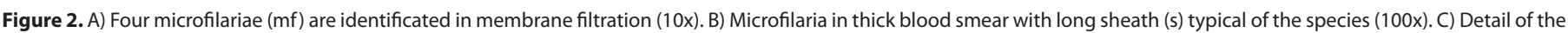
tail with nuclei $(n)$ reaching the tip in stained membrane (100x).

Table 2. Clinical and epidemiological features of the 3 filariases

\begin{tabular}{|c|c|c|c|}
\hline & Loiasis & Mansonella & Onchocerciasis \\
\hline Agent & Loaloa & Mansonella perstans & Onchocerca volvulus \\
\hline Transmission & Bite of infected Chrysops fly & Tiny blood sucking mosquitos (Culicoides) & Bite of infected Simulium blackfly \\
\hline $\begin{array}{l}\text { Geographical } \\
\text { distribution }\end{array}$ & Central and Western África & $\begin{array}{l}\text { Central África, parts of Central and } \\
\text { South America }\end{array}$ & $\begin{array}{l}\text { Equatorial África and indigenous tribes } \\
\text { in the Amazon Forest }\end{array}$ \\
\hline $\begin{array}{l}\text { Body location of } \\
\text { adult worms }\end{array}$ & Subcutaneous tissues & $\begin{array}{l}\text { Body cavities, mesentery, perirenal, } \\
\text { and retroperitoneal tissues and } \\
\text { ocasionally subcutaneously }\end{array}$ & Subcutaneous nodules \\
\hline Skin symptoms & $\begin{array}{l}\text { Asymptomatic or red, itchy swellings } \\
\text { under the skin (Calabar swellings) }\end{array}$ & $\begin{array}{l}\text { Asymptomatic or angioedema-like } \\
\text { swellings, pruritus }\end{array}$ & $\begin{array}{l}\text { Intense itching, swelling and } \\
\text { inflammation, skin atrophy }\end{array}$ \\
\hline Ocular manifestations & $\begin{array}{l}\text { Asymptomatic or severe eye itching } \\
\text { and discomfort } \\
\text { (subconjunctival adult worm) or uveitis/ } \\
\text { cataract/blindness (intraocular worm) }\end{array}$ & $\begin{array}{l}\text { Nodules in the conjunctiva, swelling } \\
\text { of the eyelids and proptosis } \\
\text { (intraocular worm rarely found) }\end{array}$ & $\begin{array}{l}\text { Punctate corneal opacities, sclerosing } \\
\text { keratitis, chorioretinal atrophy, subretinal } \\
\text { fibrosis, optic neuropathy, uveitis }\end{array}$ \\
\hline $\begin{array}{l}\text { Extra-ocular } \\
\text { manifestations }\end{array}$ & $\begin{array}{l}\text { Nephropathy, cardiomyopathy, } \\
\text { encephalopathy }\end{array}$ & $\begin{array}{l}\text { Fever, headache, pain in bursae and/or joint } \\
\text { synovia, or, in serous cavities, severe } \\
\text { abdominal pain specially in the liver region }\end{array}$ & $\begin{array}{l}\text { Subcutaneous nodules, } \\
\text { adenomegaly, fever }\end{array}$ \\
\hline
\end{tabular}

of periorbital tissues into the subconjunctival space or develop from a microfilaria inside the anterior chamber of the eye. When the adult worm is found only in the conjunctiva, severe ocular morbidity is null. However, when the adult develops in the anterior chamber, it may be accompanied by chronic uveitis, cataract, glaucoma, corneal edema, depending on the age of the patient and time of diagno$\mathrm{sis}^{(3,4)}$. The exact mechanisms of microfilarial migration into the eye chambers remain speculative. It has been hypothesized that they might come from the ciliary vessels or penetrate directly through the sclera ${ }^{(5)}$.

The definitive diagnosis of the type of filariasis should be definitely done by morphological evaluation of the adult worm and more importantly, analysis of the microfilariae. Nonetheless, some patients may not have them detectable in the blood due to the following reasons: a) diurnal periodicity of Loa loa microfilariae, b) infestation by a sole male or female adult and/or c) low parasitaemia load. The distinction from Mansonella may also be possible only by morphological analysis ${ }^{(1)}$. In our case, the adult specimen was a male but even though, the patient had positive microfilaraemia, which presumes the existence of other gravid female adult(s). Sometimes, infected individuals do not present any symptoms. The worms can incubate for months and even years before they start to migrate. This is the reason why some patients (as in the present case) may be asymptomatic for years after the first exposure to the agent ${ }^{(1)}$.

Surgical removal of the adult worm from the subconjunctival space is always recommended. Still, systemic treatment should be considered for eradication of remaining adult worms and microfilariae in order to reduce transmission (1). Several options of anti-helminthic drugs have been described, but it is important to be aware that rapid killing of microfilariae in heavy infections with Loa loa can provoke encephalopathy, a serious complication that has been described when treating with ivermectin ${ }^{(13)}$. Ivermectin and diethylcarbamazine have been classically used to reduce microfilaraemia, but albendazole may be a safer option because of its slower onset of action and lower risk of precipitating encephalopathy ${ }^{(14)}$. The concomitant use of anti-histaminic drugs or corticosteroids also seems to reduce the risk of this complication. A 21-day regimen of $400 \mathrm{mg}$ oral albendazole is considered safe and effective for individual cases. Also, repeated courses may be necessary, as microfilaraemia may reappear after months to years of the initial treatment $t^{(13,14)}$.

\section{REFERENCES}

1. Padgett JJ, Jacobsen KH. Loiasis: African eye worm. Trans R Soc Trop Med Hyg. 2008; 102(10):983-9.

2. Jain R, Chen JY, Butcher AR, Casson R, Selva D. Subconjunctival Loa loa worm. Int J Infect Dis. 2008;12(6):e133-5.

3. Eballe AO, Epée E, Koki G, Owono D, Mvogo CE, Bella AL. Intraocular live male filarial Loa loa worm. Clin Ophthalmol. 2008;2(4):965-7.

4. Barua P, Barua N, Hazarika NK, Das S. Loa loa in the anterior chamber of the eye: a case report. Indian J Med Microbiol. 2005;23(1):59-60.

5. Cho HY, Lee YJ, Shin SY, Song HO, Ahn MH, Ryu JS. Subconjuctival Loa loa with Calabar swelling. J Korean Med Sci. 2008;23(4):731-3.

6. Varhaug P. Subconjunctival Loa loa: first case report from Norway. Acta Ophthalmol. 2009;87(8):929-30.

7. Aiello F, Palma S, Varesi C, Cerulli A, Valente R, Aiello L. A rare case report of Loa loa ocular filariasis. Eur J Ophthalmol. 2010;20(1):237-9.

8. Bowler GS, Shah AN, Bye LA, Saldana M. Ocular loiasis in London 2008-2009: a case series. Eye. 2011;25(3):389-91.

9. López-Rodríguez I, De-La-Fuente-Cid R, Carnero-López JM, Cordido-Carballido M, 
Zúñiga-Rodríguez C. Loiasis. [Approach to a form of ocular parasitosis]. Arch Soc Esp Oftalmol. 2007;82(1):55-8. Spanish

10. Nam JN, Reddy S, Charles NC. Surgical management of conjunctival loiasis. Ophthal Plast Reconstr Surg. 2008:24(4):316-7.

11. Sbeity ZH, Jaksche A, Martin S, Loeffler KU. Loa loa macrofilariasis in the eyelid: case report of the first periocular subcutaneous manifestation in Germany. Graephes Arch Clin Exp Ophthalmol. 2006:244(7):883-4.

12. Newland HS, White AT, Greene BM, Murphy RP, Taylor HR. Ocular manifestations of onchocerciasis in a rain forest area of west Africa. Br J Ophthalmol. 1991;75(3): 163-9.

13. Kombila M, Duong TH, Ferrer A, Perret JL, Marion MC, Nguiri C, et al. Short- and longterm action of multiple doses of ivermectin on loiasis microfilaremia. Am J Trop Med Hyg. 1998;58(4):458-60.

14. Klion AD, Massougbodji A, Horton J, Ekoué S, Lanmasso T, Ahouissou NL, Nutman TB. Albendazole in human loiasis: results of a double-blind, placebo-controlled trial. J Infect Dis. 1993;168(1):202-6. 